\title{
Effects of timing of palmitic acid supplementation during early lactation on nutrient digestibility, energy balance, and metabolism of dairy cows
}

\author{
J. de Souza, ${ }^{1}$ C. Strieder-Barboza, ${ }^{2}$ G. A. Contreras, ${ }^{2}$ and A. L. Lock ${ }^{1 *}$ \\ ${ }^{1}$ Department of Animal Science, and \\ ${ }^{2}$ Department of Large Animal Clinical Sciences, Michigan State University, East Lansing 48824
}

\section{ABSTRACT}

The objective of our study was to evaluate the effects of timing of palmitic acid (C16:0) supplementation during early lactation on nutrient digestibility, energy intake and balance, and metabolic responses of dairy cows. Fifty-two multiparous cows were used in a randomized complete block design experiment. During the fresh (FR) period (1-24 d in milk) cows were assigned to either a control diet containing no supplemental fat $(\mathrm{CON})$ or a $\mathrm{C} 16: 0$-supplemented diet $[\mathrm{PA} ; 1.5 \%$ of diet dry matter (DM)]. During the peak (PK) period (25-67 $\mathrm{d}$ in milk) cows were assigned to either a $\mathrm{CON}$ diet or a PA diet ( $1.5 \%$ of diet $\mathrm{DM})$ in a $2 \times 2$ factorial arrangement of treatments considering the diet that they received during the FR period. During the FR period, compared with CON, PA increased DM digestibility by 3.0 percentage units and neutral detergent fiber (NDF) digestibility by 4.4 percentage units, and the increase in these variables was consistent over time. Although PA did not affect 18-carbon fatty acid (FA) digestibility, it decreased 16-carbon FA digestibility by 10.8 percentage units and total FA digestibility by 4.7 percentage units compared with CON. We observed a tendency for an interaction between treatment and time for total FA digestibility and 16-carbon FA digestibility due to the difference in FA digestibility between PA and CON reducing over time. Compared with CON, PA increased digestible energy intake by $3.9 \mathrm{Mcal} / \mathrm{d}$, metabolizable energy intake by $3.5 \mathrm{Mcal} / \mathrm{d}$, and net energy for lactation intake by $2.5 \mathrm{Mcal} / \mathrm{d}$. The PA diet also increased milk energy output, negative energy balance, and plasma nonesterified fatty acid concentration and reduced plasma insulin concentration. We also observed a tendency for an interaction between treatment and time for energy balance due to cows receiving the PA treatment being in a greater negative energy balance over time. During the PK period, PA increased DM

Received April 26, 2018.

Accepted September 10, 2018.

*Corresponding author: allock@msu.edu digestibility by 2.9 percentage units and NDF digestibility by 3.5 percentage units compared with CON. Although PA decreased 16-carbon FA digestibility by 7.0 percentage units, PA did not affect 18-carbon FA digestibility or total FA digestibility. Feeding PA during the PK period increased energy intake and milk energy output and did not affect energy balance. In conclusion, feeding a C16:0 supplement to early-lactation cows consistently increased DM and NDF digestibilities and energy intake compared with a control diet containing no supplemental fat. Feeding C16:0 markedly increased milk energy output in both the FR and PK periods but increased negative energy balance only in the FR period.

Key words: palmitic acid, early lactation, energy balance, nutrient digestibility

\section{INTRODUCTION}

The onset of lactation is a critical phase for health, fertility, and productivity of dairy cows (Zebeli et al., 2015). Lactogenesis, uterine involution, and pronounced changes in endocrine function and energy balance create a unique set of challenges that trigger major adaptive changes in the metabolic function of dairy cows (Bradford et al., 2015). The major nutritional challenge is to meet the increasing requirements for energy and key nutrients while feed intake is limited. As part of the metabolic adaptive mechanisms, body fat reserves are mobilized around parturition due to reduced plasma insulin concentration (Zachut et al., 2013), low insulin sensitivity of extrahepatic tissues (Bell, 1995), and increased catecholamine-stimulated lipolysis (Contreras et al., 2017). Increased mobilization of body reserves results in increased plasma nonesterified fatty acid (NEFA) concentration (González et al., 2011). Because the control of feed intake is likely dominated by hepatic oxidation of NEFA during the immediate postpartum period (Allen et al., 2009), the increased NEFA supply to the liver can further decrease energy intake, thereby intensifying negative energy balance (Allen and Piantoni, 2013). Additionally, elevated plasma NEFA 
concentrations can alter immune function and may increase the risk and severity of both metabolic and infectious diseases (Sordillo et al., 2009; Sordillo, 2016). Nutrient status plays a critical role during early lactation; therefore, nutrition-based management strategies to increase energy intake and minimize negative energy balance are essential.

Several nutritional strategies have been suggested to improve the metabolic adaptation of the dairy cow around parturition. To support energy demands after parturition and decrease mobilization of body reserves, diets with high energy density could be used (Piantoni et al., 2015a,b). Grummer (1993) hypothesized that dietary fat could contribute to reducing fatty acid (FA) mobilization and spare glucose by decreasing the NADPH needed for mammary FA synthesis. Limited research is available, and results are inconsistent regarding the effects of FA supplementation to early-lactation cows on energy balance and metabolism. Piantoni et al. (2015b) observed that feeding a SFA supplement $(\mathrm{C} 16: 0+\mathrm{C} 18: 0)$ at $2.0 \%$ of diet DM during the first 4 wk postpartum interacted with forage NDF level on the response of dairy cows; when the SFA supplement was fed in a low-forage diet (20\% of forage NDF), it increased energy intake and energy balance and reduced body fat mobilization at the expense of milk yield. The high-forage diet with supplemental SFA increased DMI and tended to decrease BCS loss compared with the same diet without SFA supplementation. Weiss and Pinos-Rodríguez (2009) reported an interaction among SFA supplementation, dietary forage NDF content, and time in early-lactation cows (21-126 DIM): diets supplemented with a SFA supplement $(\mathrm{C} 16: 0+\mathrm{C} 18: 0)$ increased predicted $\mathrm{NE}_{\mathrm{L}}$ intake in both high- and lowforage NDF diets before cows reached peak milk, but lower forage NDF diets increased predicted $\mathrm{NE}_{\mathrm{L}}$ intake after peak lactation regardless of fat supplementation. Although these results suggest a positive effect of FA supplementation on production and metabolic responses of early-lactation dairy cows, it is possible that the magnitude of response may vary due to the timing when the supplement is fed.

Recently, considerable research has focused on C16:0, and results have indicated that feeding C16:0 supplements in postpeak dairy cows ( $>75$ DIM) increased energy intake, NDF digestibility, and energy partitioning to milk, with no effect on BW when compared with control diets containing no supplemental fat (Piantoni et al., 2013; de Souza et al., 2017, 2018). However, research on C16:0 supplementation has been conducted only evaluating production and metabolic responses in postpeak cows. This raises a question about when during early lactation C16:0 supplementation could be used to improve the metabolic and productive responses of dairy cows. Therefore, the objective of our study was to evaluate the effects of timing of C16:0 supplementation during early lactation on nutrient digestibility, energy intake and balance, and metabolic responses of dairy cows. We hypothesized that feeding a C16:0-enriched supplement will increase energy intake and milk energy output in early-lactation cows and that production and metabolic responses to supplemental C16:0 would be greater if supplementation started after 3 wk of parturition.

\section{MATERIALS AND METHODS}

This paper is the second from an experiment that evaluated the effects of timing of C16:0 supplementation on performance and metabolism of early-lactation cows. This paper describes the effect of these diets on nutrient digestibility, energy intake, energy balance, and plasma metabolites and hormones. The companion paper (de Souza and Lock, 2018) describes treatment effects on DMI, yield of milk and milk components, and milk FA profile.

\section{Design and Treatment Diets}

Fifty-two multiparous Holstein cows from the Michigan State University Dairy Field Laboratory were used in a randomized complete block design experiment with a $2 \times 2$ factorial arrangement of treatments. Cows were blocked by BCS (up to 0.50-unit difference using a scale of $1=$ thin and $5=$ fat in 0.25 increments), previous lactation 305-d mature-equivalent yield (within 1,500 $\mathrm{kg}$ ), and parity (up to 1 lactation difference). The BCS used to block cows was the last measurement (30 d) before parturition. Cows within each block were randomly assigned to treatment based on expected parturition date. During the fresh (FR) period (1-24 DIM) cows were assigned to either a control diet containing no supplemental fat $(\mathbf{C O N})$ or a C16:0-supplemented diet (PA; $1.5 \%$ of diet DM). During the peak (PK) period (25-67 DIM) cows were also assigned to either a CON diet or a PA diet $(1.5 \%$ of diet DM) in a $2 \times 2$ factorial arrangement of treatments considering the diet that they received during the FR period. The C16:0 supplement (Palmit 80, 85.1\% C16:0, 2.7\% C18:0, 8.9\% cis-9 C18:1, and 99.0\% total FA; Global Agri-Trade Corporation, Rancho Dominguez, CA) was added at $1.5 \%$ of diet DM and replaced soyhulls in the CON diets. Treatment diets were mixed daily in a tumble mixer and were fed from the morning following parturition. The FR diets contained $24 \%$ forage NDF, $23.5 \%$ starch, and $17.5 \% \mathrm{CP}$. The PK diets contained $21 \%$ forage NDF, $27.4 \%$ starch, and $16.8 \% \mathrm{CP}$. The ingredient and nutrient composition of the diets fed as TMR, 
including the close-up ration for reference, as well as a summary of all health incidents during the treatment period are reported in the companion article (de Souza and Lock, 2018).

\section{Data and Sample Collection}

Milk yield, amount of feed offered and refused, BW, and BCS were recorded and samples of milk, feed ingredients, and orts were collected and stored as described in de Souza and Lock (2018). Samples and body measurements were collected or recorded on the same day of the week during the entire experiment so that all collection days are $\pm 3 \mathrm{~d}$.

On d 5, 12, 19, 33, 47, and 61 postpartum, fecal samples $(500 \mathrm{~g})$ were collected every $6 \mathrm{~h}$, representing every $6 \mathrm{~h}$ of a 24-h period to account for diurnal variation, for nutrient digestibility analysis. Feces were stored in sealed plastic cups at $-20^{\circ} \mathrm{C}$ until dried. Blood samples were collected on the same days as fecal samples by venipuncture of coccygeal vessels within $1 \mathrm{~h}$ before feeding. Blood was collected into 2 evacuated tubes, 1 containing potassium EDTA and the other containing potassium oxalate with sodium fluoride as a glycolytic inhibitor. Both were centrifuged at 2,000 $\times g$ for $15 \mathrm{~min}$ immediately after sample collection, and plasma was harvested and stored at $-20^{\circ} \mathrm{C}$ until analysis.

\section{Sample Analysis}

Diet ingredients, orts, and fecal samples were dried at $55^{\circ} \mathrm{C}$ in a forced-air oven for $72 \mathrm{~h}$ for $\mathrm{DM}$ determination. Dried samples were ground with a Wiley mill (1-mm screen; Arthur H. Thomas, Philadelphia, PA). Feed ingredients, orts, and feces were analyzed for NDF, CP, starch, and FA concentrations as described by Boerman et al. (2017). Gross energy was assayed by bomb calorimeter (Parr Instrument Inc., Moline, IL). Indigestible NDF was used as an internal marker to estimate fecal output to determine the apparent totaltract digestibility of nutrients (Cochran et al., 1986). Indigestible NDF was estimated as NDF after a 240-h in vitro fermentation (Goering and Van Soest, 1970). Serum concentrations of NEFA, BHB, total cholesterol, glucose, albumin, and calcium were determined using an Olympus AU640e chemistry analyzer (Olympus America, Center Valley, PA) at the Diagnostic Center for Population and Animal Health of Michigan State University (Lansing) with intra- and interassay coefficients of variation of $<3 \%$. Serum insulin concentrations were determined by ELISA (Bovine Insulin ELISA; Mercodia AB, Uppsala, Sweden) with intra- and interassay coefficients of variation of 4.50 and $4.35 \%$, respectively.
Energy intakes and balance were calculated using equations (NRC, 2001) according to Harvatine and Allen (2006). Digestible energy (DE) intake was calculated as $\mathrm{DE}=$ gross energy intake $\times$ gross energy digestibility; $\mathrm{NE}_{\mathrm{L}}$ intake was calculated from $\mathrm{DE}$ according to NRC (2001). Milk energy output (Mcal/d) was calculated according to NRC (2001) as milk energy output $(\mathrm{Mcal} / \mathrm{d})=[9.29 \times$ fat $(\mathrm{kg})+5.63 \times$ true protein $(\mathrm{kg})+3.95 \times$ lactose $(\mathrm{kg})]$, where each component was based on the average output of a cow during the week. Energy for maintenance (Mcal/d) was calculated as $0.08 \mathrm{Mcal} / \mathrm{kg} \times \mathrm{BW}(\mathrm{kg})^{0.75}$, and energy balance (Mcal/d) was determined as $\mathrm{NE}_{\mathrm{L}}$ intake $(\mathrm{Mcal} / \mathrm{d})$ milk $\mathrm{NE}_{\mathrm{L}}(\mathrm{Mcal} / \mathrm{d})-\mathrm{NE}_{\mathrm{L}}$ maintenance requirement (Mcal/d; NRC, 2001).

\section{Statistical Analysis}

Data were analyzed separately for FR (1-24 d postpartum) and for PK (25-67 d postpartum). All weekly data were analyzed using the MIXED procedure of SAS version 9.2 (SAS Institute Inc., Cary, NC) with repeated measures.

For the FR period, the model used was

$$
\begin{aligned}
\mathrm{Y}_{\mathrm{ijklm}}= & \mu+\mathrm{B}_{\mathrm{i}}+\mathrm{C}\left(\mathrm{B}_{\mathrm{i}} \mathrm{F}_{\mathrm{k}}\right)_{\mathrm{j}}+\mathrm{F}_{\mathrm{k}}+\mathrm{T}_{1} \\
& +\mathrm{J}_{\mathrm{m}}+\mathrm{F}_{\mathrm{k}} \mathrm{T}_{1}+\mathrm{e}_{\mathrm{ijk} \mathrm{k}},
\end{aligned}
$$

where $Y_{\mathrm{ijklm}}$ is the dependent variable, $\mu=$ overall mean; $\mathrm{B}_{\mathrm{i}}=$ random effect of block; $\mathrm{C}\left(\mathrm{B}_{\mathrm{i}} \mathrm{K}_{\mathrm{k}} \mathrm{S}_{1}\right)_{\mathrm{j}}=$ random effect of cow within block and treatment diet; $F_{k}=$ fixed effect of treatment during the FR period; $\mathrm{T}_{1}=$ fixed effect of time; $\mathrm{J}_{\mathrm{m}}=$ random effect of Julian date; $\mathrm{F}_{\mathrm{k}} \mathrm{T}_{1}$ $=$ fixed effect of the interaction between treatment during the FR period and time; and $\mathrm{e}_{\mathrm{ijklm}}=$ residual error.

For PK period, the model used was

$$
\begin{aligned}
& Y_{i j k l m n}=\mu+B_{i}+C\left(B_{i} F_{k} L_{l}\right)_{j}+F_{k}+L_{l}+F_{k} L_{l} \\
& +T_{m}+J_{n}+F_{k} T_{m}+L_{l} T_{m}+F_{k} L_{l} T_{m}+e_{i j k l m n}
\end{aligned}
$$

where $\mathrm{Y}_{\mathrm{ijk} k \mathrm{mn}}$ is the dependent variable, $\mu=$ overall mean; $\mathrm{B}_{\mathrm{i}}=$ random effect of block; $\mathrm{C}\left(\mathrm{B}_{\mathrm{i}} \mathrm{K}_{\mathrm{k}} \mathrm{S}_{1}\right)_{\mathrm{j}}=$ random effect of cow within block and treatment diet; $\mathrm{F}_{\mathrm{k}}$ $=$ fixed effect of treatment during the FR period; $\mathrm{L}_{1}=$ fixed effect of treatment during the PK period; $\mathrm{F}_{\mathrm{k}} \mathrm{L}_{1}=$ fixed effect of the interaction between treatment during the FR period and treatment during the PK period; $\mathrm{T}_{\mathrm{m}}=$ fixed effect of time; $\mathrm{J}_{\mathrm{n}}=$ random effect of Julian date; $F_{k} T_{m}=$ fixed effect of the interaction between treatment during the FR period and time; $\mathrm{L}_{\mathrm{l}} \mathrm{T}_{\mathrm{m}}=$ fixed effect of the interaction between treatment during the PK period and time; $F_{k} L_{l} T_{m}=$ fixed effect of the 
Table 1. Nutrient intake and total-tract nutrient digestibility for cows fed treatment diets during the fresh period (d 1-24 postpartum)

\begin{tabular}{|c|c|c|c|c|c|c|}
\hline \multirow[b]{2}{*}{ Variable } & \multicolumn{2}{|c|}{ Treatment $^{1}$} & \multirow[b]{2}{*}{ SEM } & \multicolumn{3}{|c|}{$P$-value ${ }^{2}$} \\
\hline & $\mathrm{CON}$ & PA & & Trt & Time & Trt $\times$ time \\
\hline \multicolumn{7}{|l|}{ Intake, $\mathrm{kg} / \mathrm{d}$} \\
\hline DM & 22.3 & 22.1 & 0.62 & 0.92 & $<0.01$ & 0.91 \\
\hline $\mathrm{NDF}$ & 6.89 & 6.57 & 0.21 & 0.25 & $<0.01$ & 0.59 \\
\hline \multicolumn{7}{|l|}{ Intake, $\mathrm{g} / \mathrm{d}$} \\
\hline Total FA & 675 & 992 & 24.2 & $<0.01$ & $<0.01$ & 0.24 \\
\hline 16 carbon & 126 & 396 & 8.52 & $<0.01$ & $<0.01$ & 0.18 \\
\hline 18 carbon & 515 & 570 & 15.5 & 0.01 & $<0.01$ & 0.49 \\
\hline \multicolumn{7}{|c|}{ Digestibility, \% } \\
\hline DM & 63.5 & 66.5 & 0.28 & $<0.01$ & $<0.01$ & 0.59 \\
\hline $\mathrm{NDF}$ & 35.7 & 40.1 & 0.58 & $<0.01$ & 0.16 & 0.58 \\
\hline Total FA & 83.4 & 78.7 & 0.83 & $<0.01$ & 0.82 & 0.15 \\
\hline 16 carbon & 78.2 & 67.4 & 1.19 & $<0.01$ & 0.31 & 0.14 \\
\hline 18 carbon & 86.6 & 87.5 & 0.68 & 0.35 & 0.12 & 0.39 \\
\hline \multicolumn{7}{|c|}{ Absorbed FA, g/d } \\
\hline Total FA & 563 & 778 & 19.5 & $<0.01$ & $<0.01$ & 0.15 \\
\hline 16 carbon & 98.6 & 266 & 6.65 & $<0.01$ & $<0.01$ & 0.01 \\
\hline 18 carbon & 445 & 498 & 13.1 & $<0.01$ & $<0.01$ & 0.29 \\
\hline
\end{tabular}

${ }^{1}$ Diets fed during the fresh period (1-24 DIM) were either a control diet (CON) or a diet supplemented with C16:0-enriched fatty acid supplement replacing soyhulls (PA; $1.5 \%$ of diet DM).

${ }^{2} P$-values refer to the ANOVA results for the main effect of treatment (Trt), the main effect of time, and the interaction between treatment and time.

interaction between treatment during the FR and PK periods and time; and $\mathrm{e}_{\mathrm{ijklmn}}=$ residual error.

Unless otherwise specified, first-order autoregressive was the covariate structure used for analysis because it resulted in the lowest Bayesian information criterion for most of the variables measured. Normality of the residuals was checked with normal probability and box plots and homogeneity of variances with plots of residuals versus predicted values. Significance was determined at $P \leq 0.05$ for main effects and $P \leq 0.10$ for interactions. Tendencies were determined at $P \leq 0.10$ for main effects and $P \leq 0.15$ for interactions. When interactions were at $P \leq 0.15$, the slice option was used to evaluate treatment effects within time or the effect of PK treatments within FR treatments, and the Bonferroni adjustment was applied to decrease the probability of type I error. All cows were in apparent good health at the beginning of the study, and treatment groups were not different in terms of 305-ME $(P=0.79)$, BW $(P=$ $0.84)$, or BCS $(P=0.43)$ precalving. Two cows $(1 \mathrm{CON}$ and $1 \mathrm{PA}$ ) had a displaced abomasum and underwent surgery and were excluded from the statistical analyses.

\section{RESULTS}

\section{Nutrient Digestibility During FR}

During the FR period, there was no effect of treatment on DMI and NDF intake (both $P>0.20$; Table 1). Compared with CON, PA increased the intake of total FA by $317 \mathrm{~g} / \mathrm{d}(P<0.01), 16$-carbon FA by 271 $\mathrm{g} / \mathrm{d}(P<0.01)$, and 18 -carbon FA by $55 \mathrm{~g} / \mathrm{d}(P<$ $0.01)$. The PA treatment increased DM digestibility by 3.0 percentage units $(P<0.01)$ and NDF digestibility by 4.4 percentage units $(P<0.01)$, with the increase in these variables being consistent over time (Figure 1). Although PA did not affect 18-carbon FA digestibility $(P=0.35)$, PA decreased 16-carbon FA digestibility by 10.8 percentage units $(P<0.01)$ and total FA digestibility by 4.7 percentage units $(P<0.01)$. Also, PA increased absorbed total FA by $215 \mathrm{~g} / \mathrm{d}(P<0.01)$, 16-carbon FA by $157 \mathrm{~g} / \mathrm{d}(P<0.01)$, and 18-carbon FA by $53 \mathrm{~g} / \mathrm{d}(P<0.01)$ compared with $\mathrm{CON}$.

We observed a tendency for an interaction between treatment and time for total FA $(P=0.15)$ and 16 -carbon FA digestibility $(P=0.14)$ due to the difference in FA digestibility between $\mathrm{PA}$ and $\mathrm{CON}$ reducing over time (Figure 2). Also, we observed a tendency for an interaction between treatment and time for absorbed total FA $(P=0.15)$ and an interaction between treatment and time for absorbed 16-carbon $(P<0.01)$ due to PA increasing absorbed FA to a greater extent over time (Table 1).

\section{Nutrient Digestibility During PK}

Compared with CON, we observed a tendency for PA to decrease NDF intake by $0.45 \mathrm{~kg} / \mathrm{d}(P=0.07$; Table 2 ) and increase DM digestibility by 2.9 percentage units $(P<0.01)$ and NDF digestibility by 3.5 percentage 


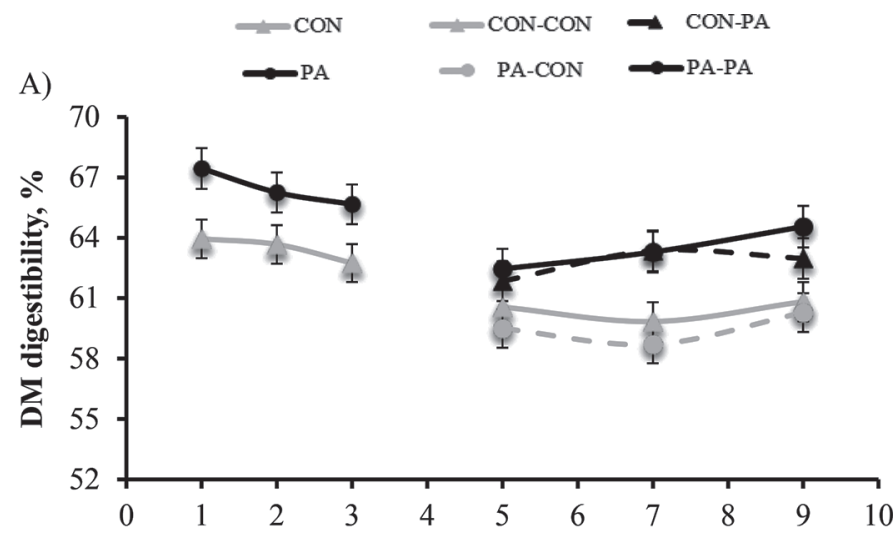

B)

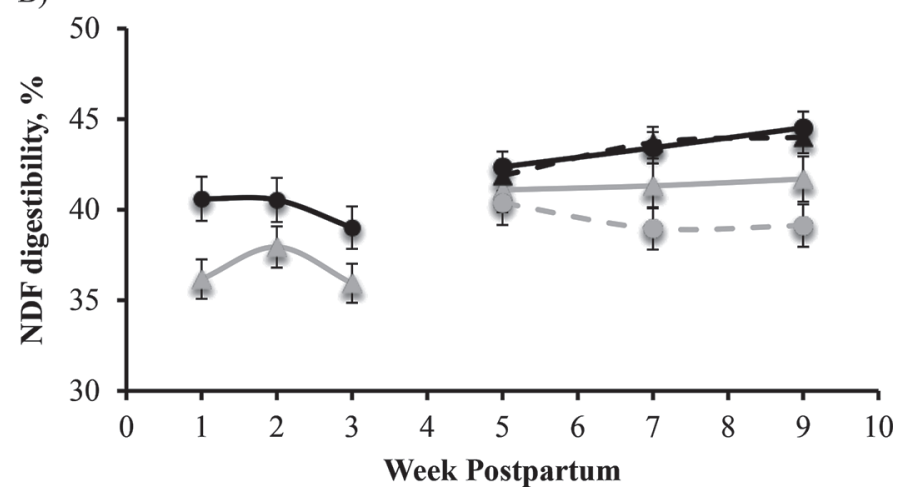

Figure 1. Effects of dietary treatments on DM digestibility (A) and NDF digestibility (B) over time during the fresh (FR; 1-24 DIM) and peak (PK; 25-67 DIM) periods. Diets fed during the FR period were either a control (CON; gray line) or 1.5\% of C16:0-enriched supplement (PA; black line). During the PK period treatments were as follows: $\mathrm{CON}-\mathrm{CON}=$ cows received $\mathrm{CON}$ for both $\mathrm{FR}$ and $\mathrm{PK}$ periods (gray line); CON-PA = cows received CON during FR and changed to the PA diet during the PK period (black dashed line); PA-CON = cows received the PA diet during the FR period and changed to the CON diet during the PK period (gray dashed line); PA-PA = cows received the $\mathrm{PA}$ diet for the $\mathrm{FR}$ and $\mathrm{PK}$ periods (black line). During the FR and PK periods, PA increased digestibilities of DM $(P<0.01)$ and NDF $(P<0.01)$ compared with CON. During the FR period, DM digestibility decreased over time in both treatments (all $P<0.01$ ), and we did not observe a treatment $\times$ time interaction for both variables. During the PK period, a tendency for an $\mathrm{FR} \times \mathrm{PK}$ diet interaction was observed for DM digestibility because feeding PA during the PK period tended to increase DM digestibility to a greater extent in cows that received the PA diet during the FR period. Error bars indicate SEM.

units $(P=0.01)$. Feeding PA during PK increased the intake of total FA by $440 \mathrm{~g} / \mathrm{d}(P<0.01), 16$-carbon FA by $359 \mathrm{~g} / \mathrm{d}(P<0.01)$, and 18 -carbon FA by $66 \mathrm{~g} / \mathrm{d}(P$ $<0.01)$ compared with CON. Although PA decreased 16-carbon FA digestibility by 7.0 percentage units $(P<$ $0.01)$, PA did not affect 18-carbon FA digestibility $(P$ $=0.31)$ and total FA digestibility $(P=0.22)$ compared with CON. Also, PA increased absorbed total FA by $288 \mathrm{~g} / \mathrm{d}(P<0.01)$ and absorbed 16 -carbon FA by
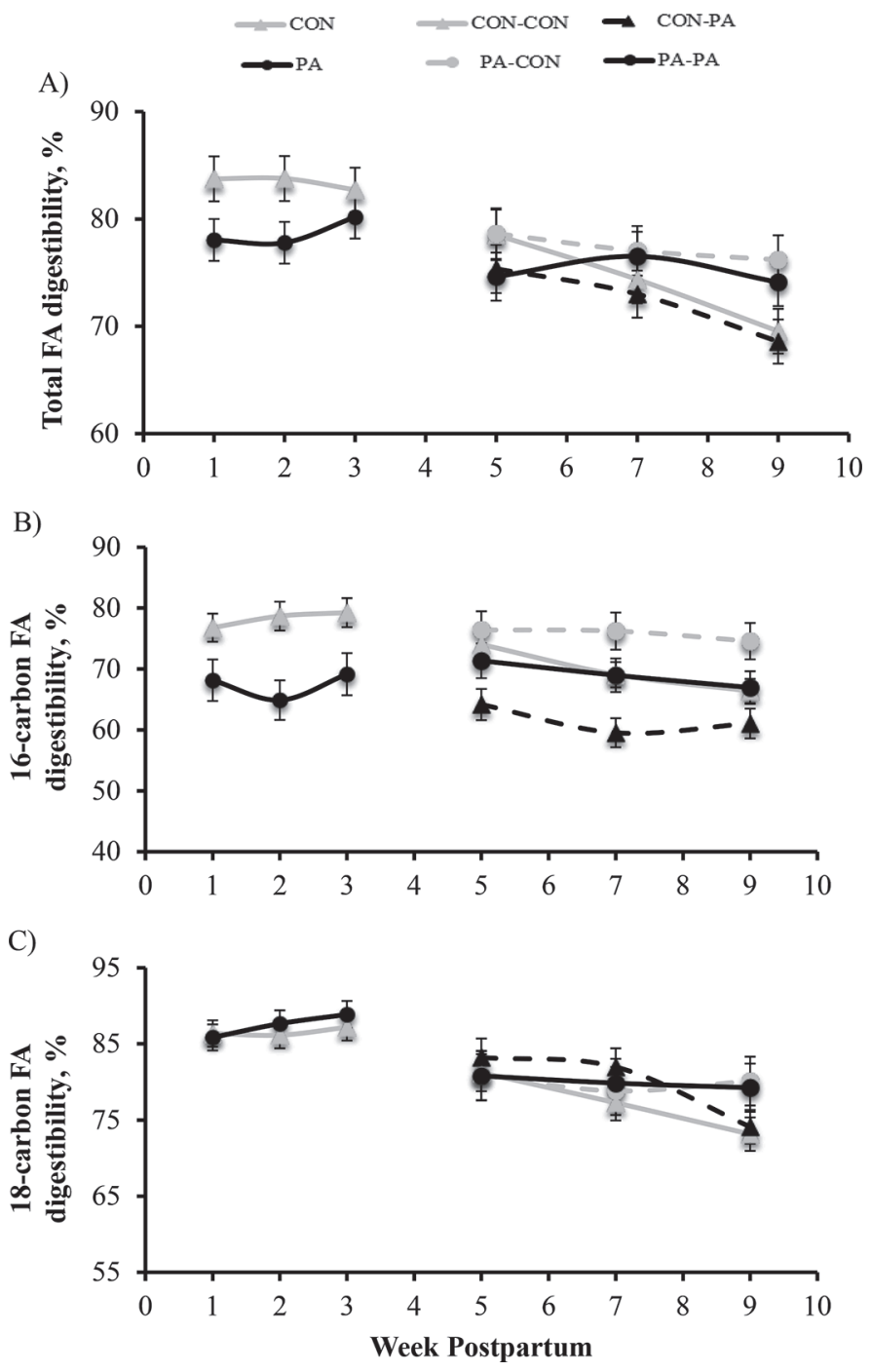

Figure 2. Effects of dietary treatments on total fatty acid (FA) digestibility (A), 16-carbon FA digestibility (B), and 18-carbon FA digestibility (C) over time during the fresh (FR; 1-24 DIM) and peak (PK; 25-67 DIM) periods. Diets fed during the FR period were either a control (CON; gray line) or 1.5\% of C16:0-enriched supplement (PA; black line). During the PK period treatments were as follows: CON$\mathrm{CON}=$ cows received $\mathrm{CON}$ for both $\mathrm{FR}$ and $\mathrm{PK}$ periods (gray line); $\mathrm{CON}-\mathrm{PA}=$ cows received $\mathrm{CON}$ during $\mathrm{FR}$ and changed to the PA diet during the PK period (black dashed line); PA-CON = cows received the PA diet during the FR period and changed to the CON diet during the PK period (gray dashed line); PA-PA = cows received the PA diet for the FR and PK periods (black line). During the FR period, PA decreased digestibilities of total FA $(P<0.01)$ and 16-carbon FA $(P$ $<0.01)$ compared with CON. We observed a tendency for an interaction between treatment and time for total FA digestibility $(P=0.15)$ and 16-carbon FA digestibility $(P=0.14)$ because the difference in FA digestibility between PA and CON reduced over time. During the PK period, PA decreased 16-carbon FA digestibility $(P<0.01)$ compared with CON. Also, we observed FR $\times$ PK diet interactions for 16-carbon $(P=0.05)$ and total FA digestibility $(P=0.03)$ because feeding PA during the PK period only reduced 16-carbon FA and total FA digestibility in cows that received the CON diet during the FR period. Error bars indicate SEM. 
$200 \mathrm{~g} / \mathrm{d}(P<0.01)$ and tended to increase absorbed 18-carbon FA by $68 \mathrm{~g} / \mathrm{d}(P=0.10)$.

The interaction between diet fed during FR and PK was not significant for most variables evaluated $(P>$ 0.15). In contrast, a tendency for a $\mathrm{FR} \times \mathrm{PK}$ interaction was observed for DM digestibility $(P=0.13)$. Feeding PA during PK tended to increase DM digestibility to a greater extent in cows that received the PA diet during the FR period $(P<0.05)$. Interestingly, feeding PA during the PK period only reduced total FA $(P<0.01)$ and 16-carbon FA digestibility $(P<0.05)$ in cows that received CON during the FR period (Figure 2).

\section{Energy Intake and Energy Balance During FR}

During the FR period, PA increased DE intake by $3.90 \mathrm{Mcal} / \mathrm{d}$ (Table $3 ; P=0.05$ ), ME intake by 3.50 $\mathrm{Mcal} / \mathrm{d}(P=0.05)$, and $\mathrm{NE}_{\mathrm{L}}$ intake by $2.50 \mathrm{Mcal} / \mathrm{d}$ $(P=0.02)$ compared with CON. The greater DE intake for PA was consistent over time compared with CON (Figure 3). Although PA did not affect energy for maintenance $(P=0.33)$, PA increased milk energy output by $3.70 \mathrm{Mcal} / \mathrm{d}(P<0.01)$ and increased negative energy balance by $-1.30 \mathrm{Mcal} / \mathrm{d}(P=0.03)$ compared with CON. The greater milk energy output for PA was consistent over time (Figure 3). There were no treatment differences for the efficiency of energy utilization for milk $\left(\mathrm{NE}_{\mathrm{L}}\right.$ milk/DE; $\left.P=0.46\right)$ or for the efficiency of energy utilization for production $\left[\left(\mathrm{NE}_{\mathrm{L}}\right.\right.$ milk $+\mathrm{NE}_{\mathrm{L}}$ maintenance)/DE; $\left.P=0.75\right]$. There were no interactions between treatment and time for most of the variables evaluated $(P>0.15)$.

\section{Energy Intake and Energy Balance During PK}

Compared with CON, PA increased DE intake by $4.90 \mathrm{Mcal} / \mathrm{d}(P=0.05$; Table 4$)$, ME intake by 4.70 $\mathrm{Mcal} / \mathrm{d}(P=0.03)$, and $\mathrm{NE}_{\mathrm{L}}$ intake by $3.40 \mathrm{Mcal} / \mathrm{d}(P$ $=0.01)$. The greater DE intake for PA was consistent over time (Figure 3). Although PA did not affect energy for maintenance $(P=0.56)$ and energy balance $(P=$ $0.19)$, PA increased milk energy output by $3.50 \mathrm{Mcal} / \mathrm{d}$ $(P<0.01)$. The greater milk energy output for PA was consistent over time (Figure 3). Additionally, energy balance increased over time in cows fed CON and PA, and both entered in a positive balance by wk 7 (Figure 3). Compared with CON, PA increased the efficiency of energy utilization for milk $\left(\mathrm{NE}_{\mathrm{L}}\right.$ milk/DE; $\left.P=0.04\right)$. There were no treatment differences for the efficiency of energy utilization for production $\left[\left(\mathrm{NE}_{\mathrm{L}}\right.\right.$ milk $+\mathrm{NE}_{\mathrm{L}}$ maintenance) $/ \mathrm{DE} ; P=0.17]$. The interaction between diet fed during FR and PK was not significant for the variables related to energy intake and balance $(P>$ $0.15)$.

Table 2. Nutrient intake and total-tract nutrient digestibility for cows fed treatment diets during the peak period (d 25-67 postpartum)

\begin{tabular}{|c|c|c|c|c|c|c|c|c|c|c|c|c|}
\hline \multirow[b]{2}{*}{ Item } & \multicolumn{4}{|c|}{ Treatment $^{1}$} & \multirow[b]{2}{*}{ SEM } & \multicolumn{7}{|c|}{$P$-value ${ }^{2}$} \\
\hline & $\mathrm{CON}-\mathrm{CON}$ & CON-PA & $\mathrm{PA}-\mathrm{CON}$ & PA-PA & & $\mathrm{FR}$ & $\mathrm{PK}$ & $\begin{array}{c}\mathrm{FR} \times \\
\mathrm{PK}\end{array}$ & Time & $\begin{array}{c}\mathrm{FR} \times \\
\text { time }\end{array}$ & $\begin{array}{c}\mathrm{PK} \times \\
\text { time }\end{array}$ & $\begin{array}{c}\mathrm{FR} \times \\
\mathrm{PK} \times \text { time }\end{array}$ \\
\hline \multicolumn{13}{|l|}{ Intake, $\mathrm{kg} / \mathrm{d}$} \\
\hline $\mathrm{DM}$ & 30.4 & 30.8 & 29.1 & 29.6 & 0.82 & 0.38 & 0.68 & 0.75 & $<0.01$ & 0.42 & 0.79 & 0.21 \\
\hline NDF & 9.38 & 9.09 & 9.55 & 8.95 & 0.25 & 0.98 & 0.07 & 0.53 & $<0.01$ & 0.49 & 0.73 & 0.51 \\
\hline \multicolumn{13}{|l|}{ Intake, g/d } \\
\hline Total FA & 1,113 & 1,576 & 1,138 & 1,554 & 39.5 & 0.98 & $<0.01$ & 0.54 & $<0.01$ & 0.74 & 0.29 & 0.18 \\
\hline 16 carbon & 213 & 578 & 220 & 572 & 15.7 & 0.97 & $<0.01$ & 0.64 & $<0.01$ & 0.82 & 0.03 & 0.31 \\
\hline 18 carbon & 868 & 950 & 884 & 934 & 25.5 & 0.99 & $<0.01$ & 0.51 & $<0.01$ & 0.63 & 0.64 & 0.15 \\
\hline \multicolumn{13}{|c|}{ Digestibility, \% } \\
\hline DM & 60.4 & 62.7 & 59.9 & 63.4 & 0.51 & 0.85 & $<0.01$ & 0.13 & 0.14 & 0.58 & 0.21 & 0.88 \\
\hline $\mathrm{NDF}$ & 41.4 & 44.2 & 39.5 & 43.4 & 1.15 & 0.49 & 0.01 & 0.37 & 0.57 & 0.77 & 0.31 & 0.85 \\
\hline Total FA & 77.3 & 72.7 & 72.8 & 72.3 & 1.91 & 0.21 & 0.22 & 0.03 & $<0.01$ & 0.18 & 0.22 & 0.93 \\
\hline 16 carbon & 73.4 & 62.4 & 69.8 & 66.6 & 2.44 & 0.15 & $<0.01$ & 0.05 & 0.42 & 0.29 & 0.27 & 0.85 \\
\hline 18 carbon & 79.9 & 80.0 & 75.9 & 79.8 & 1.92 & 0.27 & 0.31 & 0.32 & $<0.01$ & 0.18 & 0.81 & 0.82 \\
\hline \multicolumn{13}{|c|}{ Absorbed FA, g/d } \\
\hline Total FA & 813 & 1,130 & 878 & 1,137 & 39.5 & 0.32 & $<0.01$ & 0.42 & 0.05 & 0.03 & 0.31 & 0.45 \\
\hline 16 carbon & 150 & 355 & 167 & 363 & 15.1 & 0.35 & $<0.01$ & 0.74 & 0.04 & 0.65 & 0.21 & 0.85 \\
\hline 18 carbon & 660 & 751 & 706 & 750 & 27.3 & 0.39 & 0.10 & 0.35 & 0.02 & 0.44 & 0.59 & 0.19 \\
\hline
\end{tabular}

${ }^{1} \mathrm{CON}-\mathrm{CON}=$ cows received the control diet for both the fresh $(\mathrm{FR})$ and peak $(\mathrm{PK})$ periods; CON-PA $=$ cows received the control diet during the FR period and changed to the PA diet (1.5\% of C16:0-enriched fatty acid supplement replacing soyhulls) during the PK period; PA-CON $=$ cows received the $\mathrm{PA}$ diet during the $\mathrm{FR}$ period and changed to the CON diet during the PK period; PA-PA = cows received the PA diet for both the FR and PK periods.

${ }^{2} P$-values refer to the ANOVA results for the main effect of treatments during the FR and PK periods; the main effect of time; and the interactions between FR and PK treatments, FR treatment and time, PK treatment and time, and FR and PK treatments and time. 
Table 3. Energy intake, energy output and balance, and efficiency of energy utilization for cows fed treatment diets during the fresh period (d 1-24 postpartum)

\begin{tabular}{|c|c|c|c|c|c|c|}
\hline \multirow[b]{2}{*}{ Variable } & \multicolumn{2}{|c|}{ Treatment $^{1}$} & \multirow[b]{2}{*}{ SEM } & \multicolumn{3}{|c|}{$P$-value ${ }^{2}$} \\
\hline & $\mathrm{CON}$ & $\mathrm{PA}$ & & Trt & Time & Trt $\times$ time \\
\hline \multicolumn{7}{|l|}{ Energy intake, Mcal/d } \\
\hline $\mathrm{DE}^{3}$ & 62.9 & 66.8 & 1.55 & 0.05 & $<0.01$ & 0.66 \\
\hline $\mathrm{ME}^{4}$ & 53.8 & 57.2 & 1.59 & 0.05 & $<0.01$ & 0.71 \\
\hline $\mathrm{NE}_{\mathrm{L}}^{5}$ & 33.7 & 36.2 & 0.85 & 0.02 & $<0.01$ & 0.72 \\
\hline \multicolumn{7}{|l|}{ Energy output, Mcal/d } \\
\hline Milk $^{6}$ & 35.6 & 39.3 & 1.26 & $<0.01$ & 0.01 & 0.41 \\
\hline Maintenance $^{7}$ & 11.0 & 10.9 & 0.18 & 0.33 & $<0.01$ & 0.38 \\
\hline Energy balance, ${ }^{8} \mathrm{Mcal} / \mathrm{d}$ & -12.9 & -14.2 & 0.55 & 0.03 & $<0.01$ & 0.17 \\
\hline \multicolumn{7}{|l|}{ Efficiency } \\
\hline $\mathrm{NE}_{\mathrm{L}}$ milk/DE & 0.565 & 0.580 & 0.03 & 0.46 & $<0.01$ & 0.25 \\
\hline $\mathrm{NE}_{\mathrm{L}}$ production $^{9} / \mathrm{DE}$ & 0.742 & 0.744 & 0.04 & 0.75 & $<0.01$ & 0.46 \\
\hline
\end{tabular}

${ }^{1}$ Diets fed during the fresh period (1-24 DIM) were either a control diet (CON) or a diet supplemented with C16:0-enriched fatty acid supplement replacing soyhulls (PA; $1.5 \%$ of diet DM).

${ }^{2} P$-values refer to the ANOVA results for the main effect of treatment (Trt), the main effect of time, and the interaction between treatment and time.

${ }^{3}$ Digestible energy $(\mathrm{DE})$ intake $=$ gross energy intake $(\mathrm{Mcal} / \mathrm{d}) \times$ gross energy digestibility.

${ }^{4}$ Calculated from DE according to NRC (2001).

${ }^{5}$ Calculated from DE through ME according to NRC (2001).

${ }^{6}$ Milk $\mathrm{NE}_{\mathrm{L}}(\mathrm{Mcal} / \mathrm{d})=$ milk yield $(\mathrm{kg} / \mathrm{d}) \times[($ fat $\% \times 0.0929)+($ true protein $\% \times 0.0563)+($ lactose $\% \times$ 0.0395)] (NRC, 2001).

${ }^{7} \mathrm{NE}_{\mathrm{L}}$ maintenance $(\mathrm{Mcal} / \mathrm{d})=0.08 \mathrm{Mcal} / \mathrm{kg} \times \mathrm{BW}(\mathrm{kg})^{0.75}(\mathrm{NRC}, 2001)$.

${ }^{8}$ Energy balance $(\mathrm{Mcal} / \mathrm{d})=\mathrm{NE}_{\mathrm{L}}$ intake $(\mathrm{Mcal} / \mathrm{d})-$ milk $\mathrm{NE}_{\mathrm{L}}(\mathrm{Mcal} / \mathrm{d})-\mathrm{NE}_{\mathrm{L}}$ maintenance requirement (Mcal/d).

${ }^{9} \mathrm{NE}_{\mathrm{L}}$ production $=$ milk $\mathrm{NE}_{\mathrm{L}}+\mathrm{NE}_{\mathrm{L}}$ required for maintenance.

\section{Plasma Insulin and Metabolites During FR}

During the FR period, there was no effect of treatment on plasma concentrations of glucose $(P=0.18)$, BHB $(P=0.15)$, albumin $(P=0.87)$, or $\mathrm{Ca}(P=$ 0.94; Table 5). Compared with CON, PA increased plasma NEFA $(P=0.03)$ and cholesterol $(P=0.03)$ and reduced plasma insulin $(P=0.05)$. We observed an interaction between treatment and time for BHB $(P$ $=0.10)$ due to the difference in BHB between PA and CON decreasing over time (Figure 4).

\section{Plasma Insulin and Metabolites During PK}

During the PK period, we only evaluated plasma NEFA, insulin, and BHB concentrations, and the effect of diet fed during FR was not significant for these variables $(P>0.10$; Table 6$)$. During the PK period, PA decreased plasma insulin $(P=0.01)$ and tended to decrease $\mathrm{BHB}$ concentrations $(P=0.10)$ compared with CON. There was no effect of treatment on plasma NEFA $(P=0.41)$. We also observed a tendency for an interaction between diet fed during the FR and PK periods for plasma NEFA $(P=0.13)$ due to PA in the PK period increasing plasma NEFA in cows that received $\mathrm{CON}$ in the FR period; this was more pronounced at wk $5(P=0.10$; Figure 4$)$.

\section{DISCUSSION}

During the weeks following parturition, the enhanced nutrient demand for milk production requires homeorhetic adaptations to support both the increased energy demand of the mammary gland and peripheral tissue metabolism (Bauman and Currie, 1980). Several postpartum metabolic disorders are the result of insufficient nutrient intake in the period immediately surrounding parturition (McCarthy et al., 2015). Therefore, to support energy demand at parturition and modulate the excessive mobilization of body reserves, feeding supplemental fat may be a strategy to increase energy intake and reduce negative energy balance, but inconsistency in responses to supplemental fat has been observed (e.g., Sklan et al., 1994; Moallem et al., 2007; Piantoni et al., 2015a,b). This may be associated with the FA profile of supplemental fat and timing when supplementation starts. To our knowledge, scarce information exists about the effects of individual FA on performance and metabolism of early-lactation cows. In our study, we evaluated the effects of feeding a C16:0 supplement during early lactation on nutrient digestibility and metabolic responses of dairy cows; productive responses are presented in our companion paper (de Souza and Lock, 2018). 


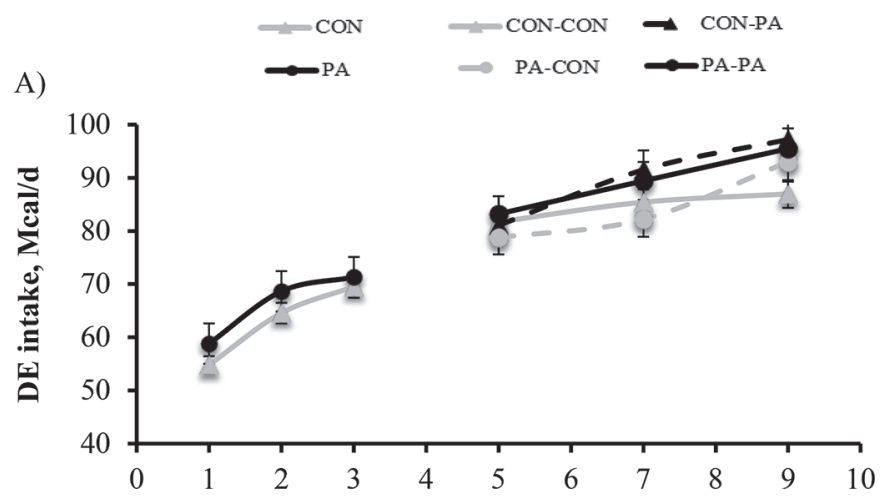

B)
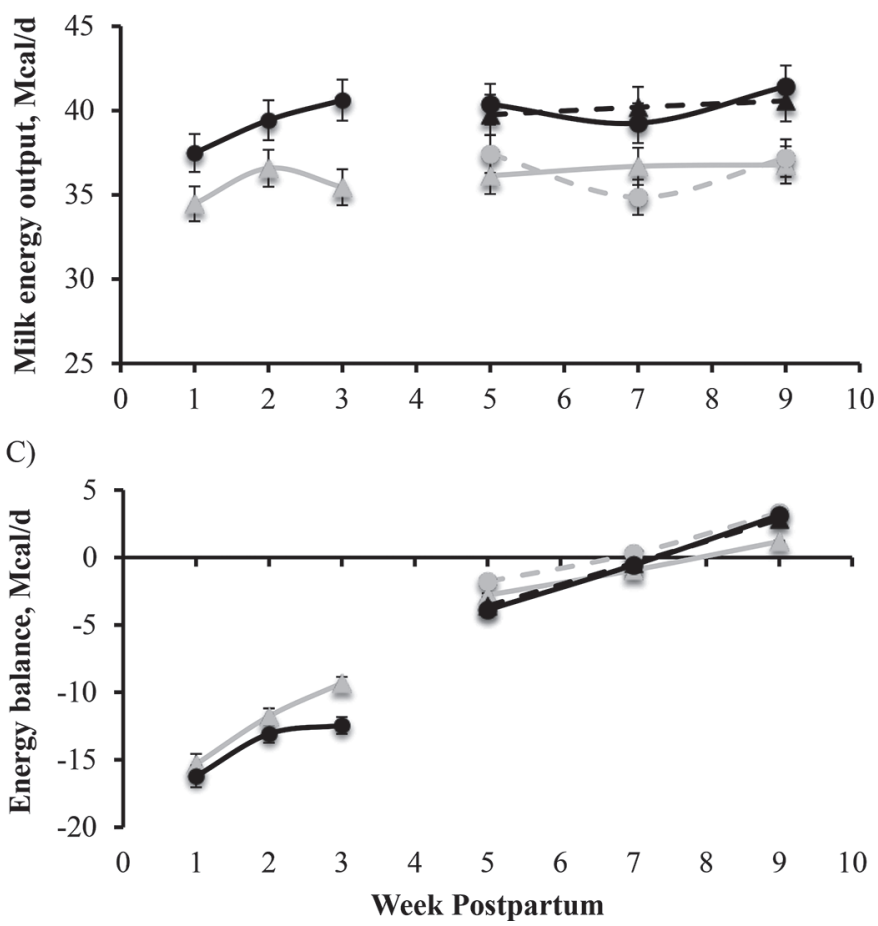

Figure 3. Effects of dietary treatments on digestible energy (DE) intake (A), milk energy output (B), and energy balance (C) over time during the fresh (FR; 1-24 DIM) and peak (PK; 25-67 DIM) periods. Diets fed during the FR period were either a control (CON; gray line) or 1.5\% of C16:0-enriched supplement (PA; black line). During the PK period treatments were as follows: $\mathrm{CON}-\mathrm{CON}=$ cows received $\mathrm{CON}$ for both FR and PK periods (gray line); CON-PA = cows received CON during FR and changed to the PA diet during the PK period (black dashed line); $\mathrm{PA}-\mathrm{CON}=$ cows received the PA diet during the FR period and changed to the CON diet during the PK period (gray dashed line); PA-PA = cows received the PA diet for the FR and PK periods (black line). During the FR period, PA increased DE intake $(P=0.05)$ and milk energy output $(P<0.01)$ and reduced energy balance $(P=0.05)$ compared with CON. We observed a tendency for an interaction between treatment and time for energy balance $(P=$ 0.15 ) due to cows receiving PA treatment being in a greater negative energy balance over time. During the PK period, PA increased DE intake $(P=0.05)$ and milk energy output $(P=0.03)$ compared with CON. Digestible energy intake, milk energy output, and energy balance increased over time for all treatments. Error bars indicate SEM.
During the FR period, we observed that PA decreased the digestibility of 16-carbon and total FA; however, the difference between treatments for these variables decreased over time. Due to these differences in FA digestibility over time, we observed that absorbed 16-carbon and total FA increased over time with PA. Bines et al. (1978) fed increasing levels of tallow in the first 13 wk of lactation and observed a quadratic response in total FA digestibility measured at wk 10 to 12 of lactation. With grazing cows, Batistel et al. (2017) reported that FA digestibility increased when cows received Ca salts of palm FA from wk 3 to 16 of lactation compared with a control diet containing no supplemental fat, but no differences over time were reported. With postpeak cows, although Rico et al. (2014) reported that feeding a C16:0 supplement had positive effects on 16-carbon and total FA digestibility of low-producing cows, other studies with high-producing cows have observed reductions in FA digestibility when feeding similar supplements (de Souza et al., 2017; Rico et al., 2017a). In a recent meta-analysis, Boerman et al. (2015) observed no reduction in FA digestibility when the duodenal flow of C16:0 increased up to $500 \mathrm{~g} / \mathrm{d}$, whereas increasing the duodenal flow of $\mathrm{C} 18: 0$ to the same level reduced FA digestibility. In our study, the intake of 16-carbon FA was lower than $500 \mathrm{~g} / \mathrm{d}$ for the PA treatments, with PA reducing FA digestibility. Although the exact mechanisms for the reduction in FA digestibility as FA intake increases are unknown, potential causes have been suggested and include competition for absorption sites and limitation in emulsification (Drackley, 2000). Additionally, in our study, reasons for the treatment differences over time may include increased intake and flow of other FA to the duodenum because feed intake increased over time. Although total flow of FA at the duodenum affects FA digestibility (Boerman et al., 2015), the profile of FA entering the duodenum is a critical factor affecting FA digestibility (Doreau and Chilliard, 1997; de Souza et al., 2018). Unsaturated FA have greater digestibility compared with SFA (Boerman et al., 2015) and may increase the solubility of SFA, facilitating transfer to micelles (Freeman, 1969) and uptake and re-esterification in enterocytes (Ockner et al., 1972). During the FR period, we first measured digestibility for PA and CON diets when cows were 5 DIM, so it is possible that cows were not totally adapted to diets and in a steady state; however, results were similar during the following 2 wk of digestibility measurements. Importantly, we also observed that feeding PA during the PK period only reduced 16-carbon and total FA in cows that received $\mathrm{CON}$ during the FR period. This may suggest some adaptive mechanism in the digestion and absorption of FA in the intestine when FA supplements are fed long term. Because most 
Table 4. Energy intake, energy output and balance, and efficiency of energy utilization for cows fed treatment diets during the peak period (d $25-67$ postpartum)

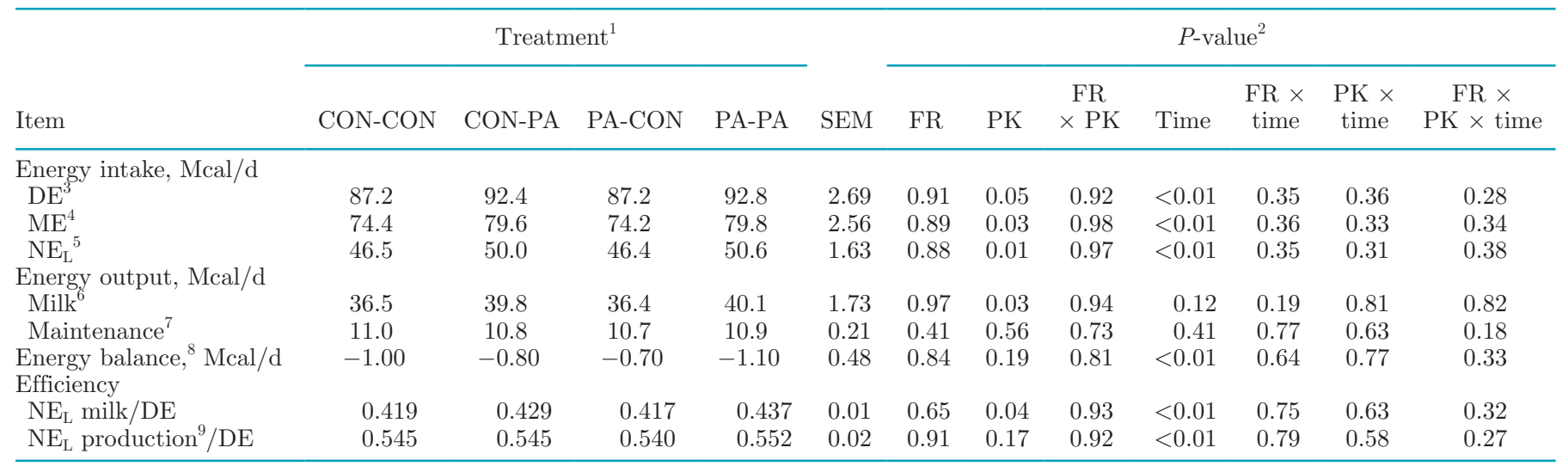

${ }^{1} \mathrm{CON}-\mathrm{CON}=$ cows received the control diet for both the fresh $(\mathrm{FR})$ and peak $(\mathrm{PK})$ periods; CON-PA = cows received the control diet during the FR period and changed to the PA diet (1.5\% of C16:0-enriched fatty acid supplement replacing soyhulls) during the PK period; PA-CON $=$ cows received the PA diet during the FR period and changed to the CON diet during the PK period; PA-PA = cows received the PA diet for both the FR and PK periods.

${ }^{2} P$-values refer to the ANOVA results for the main effect of treatments during the FR and PK periods; the main effect of time; and the interactions between FR and PK treatments, FR treatment and time, PK treatment and time, and FR and PK treatments and time.

${ }^{3}$ Digestible energy $(\mathrm{DE})$ intake $=$ gross energy intake $(\mathrm{Mcal} / \mathrm{d}) \times$ gross energy digestibility.

${ }^{4}$ Calculated from DE according to NRC (2001).

${ }^{5}$ Calculated from DE through ME according to NRC (2001).

${ }^{6} \mathrm{Milk} \mathrm{NE}_{\mathrm{L}}(\mathrm{Mcal} / \mathrm{d})=$ milk yield $(\mathrm{kg} / \mathrm{d}) \times[($ fat $\% \times 0.0929)+($ true protein $\% \times 0.0563)+($ lactose $\% \times 0.0395)](\mathrm{NRC}, 2001)$.

${ }^{7} \mathrm{NE}_{\mathrm{L}}$ maintenance $(\mathrm{Mcal} / \mathrm{d})=0.08 \mathrm{Mcal} / \mathrm{kg} \times \mathrm{BW}(\mathrm{kg})^{0.75}(\mathrm{NRC}, 2001)$.

${ }^{8}$ Energy balance $(\mathrm{Mcal} / \mathrm{d})=\mathrm{NE}_{\mathrm{L}}$ intake $(\mathrm{Mcal} / \mathrm{d})-$ milk $\mathrm{NE}_{\mathrm{L}}(\mathrm{Mcal} / \mathrm{d})-\mathrm{NE}_{\mathrm{L}}$ maintenance requirement $(\mathrm{Mcal} / \mathrm{d})$.

${ }^{9} \mathrm{NE}_{\mathrm{L}}$ production $=$ milk $\mathrm{NE}_{\mathrm{L}}+\mathrm{NE}_{\mathrm{L}}$ required for maintenance.

studies measuring digestibility in dairy cows have been conducted under short-term conditions, further studies are needed to confirm these results and to determine the potential mechanisms associated with changes in FA absorption over time.

When fed at typical inclusion rates ( $\leq 3 \%$ of $\operatorname{diet} \mathrm{DM})$, fat supplements minimally influence the digestibility of large aggregated fractions, such as DM digestibility, even when the digestibility of total FA differs markedly (Grummer, 1988; Weiss and Wyatt, 2004). However, if the supplement has effects on fiber digestion, DM digestibility can be affected (Simas et al., 1998). In our study, the PA treatments consistently increased both NDF and DM digestibilities compared with CON in both the FR and PK periods. Piantoni et al. (2015a) observed that feeding a SFA supplement (C16:0 + C18:0) increased NDF digestibility by 4.0 percentage units in a low-forage NDF diet but had no effect in a high-forage NDF diet during the immediate postpartum period (1-29 DIM). With postpeak cows, previous studies have reported that feeding C16:0 supplements increases NDF digestibility compared with control diets

Table 5. Blood metabolites for cows fed treatment diets during the fresh period (d 1-24 postpartum)

\begin{tabular}{|c|c|c|c|c|c|c|}
\hline \multirow[b]{2}{*}{ Variable } & \multicolumn{2}{|c|}{ Treatment $^{1}$} & \multirow[b]{2}{*}{ SEM } & \multicolumn{3}{|c|}{$P$-value ${ }^{2}$} \\
\hline & $\mathrm{CON}$ & PA & & Trt & Time & Trt $\times$ time \\
\hline Glucose, mg/dL & 50.4 & 45.3 & 3.27 & 0.18 & $<0.01$ & 0.24 \\
\hline Nonesterified fatty acids, $\mathrm{mmol} / \mathrm{L}$ & 0.59 & 0.65 & 0.02 & 0.03 & $<0.01$ & 0.33 \\
\hline $\mathrm{BHB}, \mathrm{mg} / \mathrm{dL}$ & 12.4 & 13.6 & 1.75 & 0.15 & $<0.01$ & 0.10 \\
\hline Insulin, $\mu \mathrm{g} / \mathrm{L}$ & 0.24 & 0.21 & 0.01 & 0.05 & $<0.01$ & 0.67 \\
\hline Albumin, g/dL & 3.04 & 3.02 & 0.15 & 0.87 & $<0.01$ & 0.45 \\
\hline Cholesterol, mg/dL & 79.5 & 89.0 & 4.29 & 0.03 & $<0.01$ & 0.43 \\
\hline Calcium, mg/dL & 8.9 & 9.0 & 0.32 & 0.94 & $<0.01$ & 0.80 \\
\hline
\end{tabular}

${ }^{1}$ Diets fed during the fresh period (1-24 DIM) were either a control diet (CON) or a diet supplemented with C16:0-enriched fatty acid supplement replacing soyhulls (PA; $1.5 \%$ of diet DM).

${ }^{2} P$-values refer to the ANOVA results for the main effect of treatment (Trt), the main effect of time, and the interaction between treatment and time. 

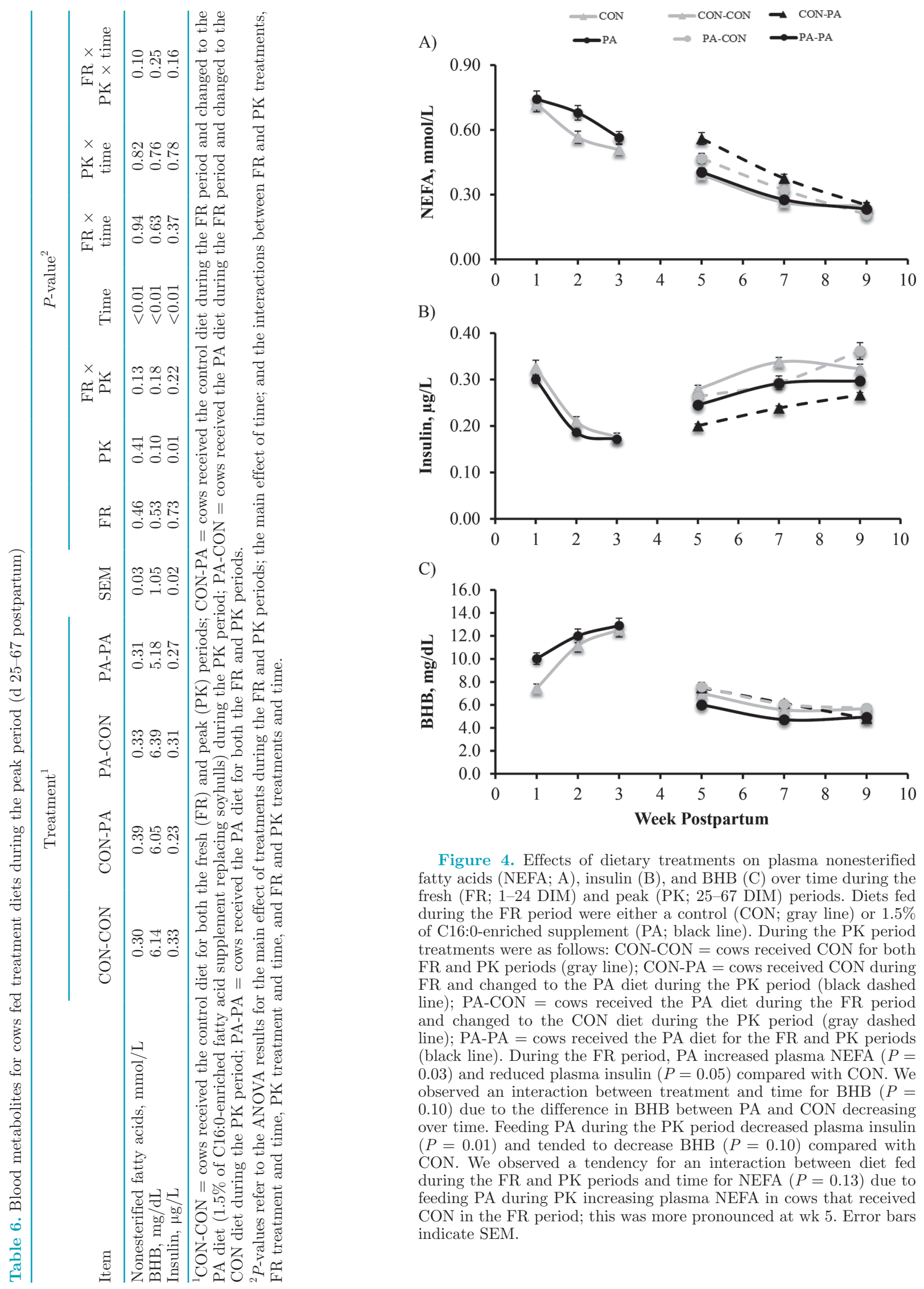

Figure 4. Effects of dietary treatments on plasma nonesterified fatty acids (NEFA; A), insulin (B), and BHB (C) over time during the fresh (FR; 1-24 DIM) and peak (PK; 25-67 DIM) periods. Diets fed during the FR period were either a control (CON; gray line) or $1.5 \%$ of C16:0-enriched supplement (PA; black line). During the PK period treatments were as follows: $\mathrm{CON}-\mathrm{CON}=$ cows received $\mathrm{CON}$ for both FR and PK periods (gray line); CON-PA = cows received CON during FR and changed to the PA diet during the PK period (black dashed line); $\mathrm{PA}-\mathrm{CON}=$ cows received the $\mathrm{PA}$ diet during the $\mathrm{FR}$ period and changed to the CON diet during the PK period (gray dashed line); PA-PA = cows received the PA diet for the FR and PK periods (black line). During the FR period, PA increased plasma NEFA $(P=$ $0.03)$ and reduced plasma insulin $(P=0.05)$ compared with $\mathrm{CON}$. We observed an interaction between treatment and time for BHB $(P=$ $0.10)$ due to the difference in BHB between PA and CON decreasing over time. Feeding PA during the PK period decreased plasma insulin $(P=0.01)$ and tended to decrease BHB $(P=0.10)$ compared with CON. We observed a tendency for an interaction between diet fed during the FR and PK periods and time for NEFA $(P=0.13)$ due to feeding PA during PK increasing plasma NEFA in cows that received $\mathrm{CON}$ in the FR period; this was more pronounced at wk 5. Error bars indicate SEM. 
containing no supplemental fat (Piantoni et al., 2013; de Souza et al., 2017) and other FA supplements (de Souza et al., 2018). This increase in NDF digestibility may be associated with an increase in retention time driven by an increase in cholecystokinin secretion (Piantoni et al., 2013). Alternatively, bacteria typically synthesize C16:0 de novo to produce phosphatidic acid, the precursor for FA components in membranes of Butyrivibrio bacteria (Hackmann and Firkins, 2015). However, if dietary C16:0 could be incorporated into rumen bacterial membranes, considerable ATP would be spared, which may favor bacterial growth (Vlaeminck et al., 2006), potentially increasing NDF digestibility. Therefore, the results of our study with early-lactation cows agree with previous findings in postpeak cows indicating a positive effect of feeding C16:0 on fiber digestibility, although the exact mechanism still needs to be determined.

Compared with CON, PA increased energy intake, including $\mathrm{DE}, \mathrm{ME}$, and $\mathrm{NE}_{\mathrm{L}}$ during both the $\mathrm{FR}$ and PK periods. Additionally, we did not observe interactions with timing of supplementation, indicating a consistent increase in energy intake when supplementing C16:0 over time. Previous studies feeding FA supplements around parturition have reported inconsistent results regarding energy intake. Piantoni et al. (2015b) reported that cows immediately postpartum (1-29 DIM) had increased energy intake $(+4.2 \mathrm{Mcal}$ of $\left.\mathrm{NE}_{\mathrm{L}} / \mathrm{d}\right)$ when fed a SFA supplement $(\mathrm{C} 16: 0+\mathrm{C} 18: 0)$ regardless of dietary forage NDF level, partially due to higher DMI in SFA-supplemented diets $(+1.4 \mathrm{~kg}$ of DMI/d). Similarly, Weiss and Pinos-Rodríguez (2009) reported an interaction among FA supplementation, dietary forage NDF content, and time in early-lactation cows (21-126 DIM): diets supplemented with a SFA supplement $(\mathrm{C} 16: 0+\mathrm{C} 18: 0)$ increased predicted $\mathrm{NE}_{\mathrm{L}}$ intake in both high- and low-forage NDF diets before cows reached peak milk, but lower forage NDF diets increased predicted $\mathrm{NE}_{\mathrm{L}}$ intake after peak lactation regardless of SFA supplementation. In contrast, Moallem et al. (2007) fed a SFA supplement (C16:0 + C18:0) during the pre- and postpartum periods and reported that the supplement did not affect predicted energy intake compared with a diet containing no supplemental fat. Consistent with these results, Beam and Butler (1998) showed that feeding a SFA supplement (C16:0 + C18:0) did not affect predicted energy intake during the first 6 wk of lactation. Reasons for these inconsistent results may include different methods for calculating or predicting energy intake, duration of the supplementation period, and the FA profile of supplemental fat. In the studies discussed above, energy intake was predicted from the diet and not actually measured as in Piantoni et al. (2015b) and in the present study. In our study, predicting $\mathrm{NE}_{\mathrm{L}}$ from dietary composition during the FR period using the NRC (2001) model would estimate that PA increased $\mathrm{NE}_{\mathrm{L}}$ intake by only $1 \mathrm{Mcal} / \mathrm{d}$, whereas our actual calculated increase in $\mathrm{NE}_{\mathrm{L}}$ intake was $2.5 \mathrm{Mcal} / \mathrm{d}$. This difference is at least in part associated with the observed increase in NDF digestibility with PA that the NRC (2001) model is not able to account for in its estimation. Similarly, using predicted energy intake from dietary composition would indicate an overestimation of negative energy balance with PA by $1.5 \mathrm{Mcal} / \mathrm{d}$ during the FR period. Considering the high variability in nutrient digestibility among cows (Piantoni et al., 2013) and the potential effect that individual FA may have on the digestibility of other fractions, using energy concentrations predicted from dietary composition is inadequate for calculating energy intake and energy balance (Piantoni et al., 2015b).

We observed that PA increased milk energy output consistently during the FR and PK periods. This was associated with PA increasing ECM in both the FR and PK periods (de Souza and Lock, 2018). Similarly, previous studies with postpeak cows have observed that C16:0 supplementation increased ECM and milk energy output (Lock et al., 2013; de Souza et al., 2018). The PA treatment increased energy intake $(+2.5$ Mcal of $\mathrm{NE}_{\mathrm{L}} / \mathrm{d}$ ); however, due to the large increase in milk energy output $(+3.7 \mathrm{Mcal} / \mathrm{d})$, we observed that PA increased negative energy balance during the FR period (average of $-1.3 \mathrm{Mcal} / \mathrm{d}$ ). Previous studies feeding FA supplements to early-lactation cows have observed inconsistent responses regarding energy balance. Piantoni et al. (2015b) reported an increase in energy balance $(+5.2 \mathrm{Mcal} / \mathrm{d})$, mainly due to a higher energy intake $\left(+4.2 \mathrm{Mcal} / \mathrm{d}\right.$ of $\left.\mathrm{NE}_{\mathrm{L}}\right)$ when feeding a SFA supplement $(\mathrm{C} 16: 0+\mathrm{C} 18: 0)$ during the immediate postpartum period regardless of dietary forage NDF content, although milk energy output was not affected by treatment. Conversely, Beam and Butler (1998) reported that SFA supplementation (C16:0 + C18:0) did not affect predicted energy balance compared with a control diet in the first 4 wk after parturition. In our study, we did not observe treatment effects on energy balance during the PK period even though we observed similar increases in milk energy output $(+3.50 \mathrm{Mcal} / \mathrm{d})$ and energy intake $\left(+3.40 \mathrm{Mcal} / \mathrm{d}\right.$ of $\left.\mathrm{NE}_{\mathrm{L}}\right)$ due to PA supplementation. Also, we observed an increase in the efficiency of utilization of DE intake to $\mathrm{NE}_{\mathrm{L}}$ in milk with $\mathrm{PA}$ compared with CON during the PK period.

Dairy cows enhance lipolysis rates during the immediate postpartum period as part of the normal homeorhetic regulation of their metabolism. In our study, the effect of PA on energy balance was consistent with higher plasma NEFA concentrations and lower insulin concentrations during the FR period, which suggests increased lipolysis and fat mobilization. Consistent with 
our blood marker results, we also observed that PA induced greater BW loss during the FR period (de Souza and Lock, 2018). In contrast, most of our short-term studies feeding C16:0 supplements to postpeak cows (fed at $1.5-2.0 \%$ of diet DM) have indicated no changes in BW and BCS compared with control diets containing no supplemental fat (Lock et al., 2013; Piantoni et al., 2013; de Souza et al., 2017). Also, previous studies with SFA supplements (C16:0 + C18:0) have indicated that supplementation had no effect (Beam and Butler, 1998) or increased (Moallem et al., 2007) or decreased (Piantoni et al., 2015b) plasma NEFA concentrations during early lactation. Although lipolysis ensures an adequate supply of energy substrate to tissues around parturition, when intense and protracted, it predisposes cows to inflammatory and metabolic diseases by limiting the capacity of adipose tissue for energy buffering and contributing to chronically increased plasma NEFA (Bradford et al., 2015; Contreras et al., 2017). Serum NEFA concentrations greater than $0.7 \mathrm{mmol} / \mathrm{L}$ in the immediate postpartum period have been described as a risk factor for the development of clinical diseases postpartum (i.e., clinical ketosis, metritis, displaced abomasum), impaired reproduction in the subsequent breeding period, and early culling from the herd (Ospina et al., 2013; Ribeiro et al., 2013). We observed that during the first week after calving the number of cows with NEFA concentrations in serum greater than 0.7 $\mathrm{mmol} / \mathrm{L}$ was similar between $\mathrm{CON}$ and PA (40 and $46 \%$ for CON and PA, respectively). During the PK period, we did not observe an effect of treatment for plasma NEFA.

Increased ketogenesis is one of the requirements for a good hepatic adaptation to the increased energy demand during the immediate postpartum period, and ketone bodies are very important alternative sources of energy for tissues when glucose is being redirected to the mammary gland (Herdt, 2000). We observed that PA increased BHB concentrations during the first week after calving compared with CON. Plasma BHB concentrations of 10 to $14 \mathrm{mg} / \mathrm{dL}$ have been suggested as cut-off points for increased risk of metabolic disorders (Ospina et al., 2013; Overton et al., 2017). Furthermore, Ospina et al. (2010) reported that cows with BHB concentrations $>10 \mathrm{mg} / \mathrm{dL}$ between 3 and 14 $\mathrm{d}$ postpartum had $>4$ times higher risk of postpartum diseases (e.g., displaced abomasum, metritis, clinical ketosis) and were $>15 \%$ less likely to be pregnant after the voluntary waiting period (by $70 \mathrm{~d}$ ). Although PA increased plasma BHB concentration in the first week of the FR period, BHB concentrations were below the threshold considered critical for increased incidence of metabolic disorders. Therefore, in our study the increases in plasma $\mathrm{BHB}$ with $\mathrm{PA}$ are likely associated with the increase in nutrient partitioning toward the mammary gland rather than an indication of metabolic dysfunction.

During the PK period, PA decreased insulin compared with CON. With postpeak cows, Mathews et al. (2016) observed a decrease in glucose-stimulated NEFA disappearance in cows fed C16:0, suggesting the possibility of localized adipose tissue insulin resistance with prolonged C16:0 supplementation. Feeding C16:0 in early lactation rapidly increased circulating ceramide, especially C24:0 ceramide (Davis et al., 2017), which is inversely associated with glucose clearance rates following an insulin challenge postpartum (Rico et al., 2017b). Because we observed decreased plasma insulin concentrations in both the FR and PK periods due to C16:0 supplementation, it is possible that the effects of C16:0 driving energy partitioning toward milk at the expense of body reserves in early lactation are at least in part associated with its effect on insulin secretion or tissue sensitivity to insulin. Altogether, our blood metabolite results agree with our energy calculations and performance outcomes, in which PA increased the yield of ECM and milk fat, partially due to inducing greater BW loss (de Souza and Lock, 2018). Although we observed that PA supplementation increased negative energy balance and markers of lipolysis during the FR period, further studies are needed to evaluate the potential effects of greater BW and BCS losses on health and reproduction of dairy cows.

\section{CONCLUSIONS}

Feeding a C16:0 supplement to early-lactation cows consistently increased DM and NDF digestibilities and energy intake compared with a control diet containing no supplemental fat. For FA digestibility, the effect of feeding C16:0 was affected by the timing of supplementation because feeding PA during PK only reduced total FA digestibility and 16-carbon FA digestibility in cows that received the CON diet during FR. Our results suggest that feeding C16:0 during early lactation increased milk energy output, reduced insulin concentration, and increased negative energy balance and plasma NEFA only when fed in the immediate postpartum period. Feeding C16:0 during PK increased energy intake and milk energy output without changes in energy balance.

\section{ACKNOWLEDGMENTS}

We acknowledge Global Agri-Trade Corporation (Rancho Dominguez, CA) for financial support of this study. We also acknowledge R. J. Tempelman (Department of Animal Science, Michigan State University, East Lansing) for the helpful discussion about statisti- 
cal analysis and Stacy Nichols (Vita Plus, Madison, WI) for the helpful discussion about diet formulation. We acknowledge C. L. Preseault, L. N. Worden, J. Guy, Y. Sun, S. Schmidt, and M. Western (all in the Department of Animal Science, Michigan State University) and the staff of the Michigan State University Dairy Cattle Teaching and Research Center for their assistance with this experiment. Jonas de Souza was supported by a $\mathrm{PhD}$ fellowship from Coordenação de Aperfoiçamento de Pessoal de Nivel Superior (CAPES) from the Brazilian Ministry of Education (Brasilia, DF, Brazil).

\section{REFERENCES}

Allen, M. S., B. Bradford, and M. Oba. 2009. Board-invited review: The hepatic oxidation theory of the control of feed intake and its application to ruminants. J. Anim. Sci. 87:3317-3334.

Allen, M. S., and P. Piantoni. 2013. Metabolic control of feed intake: Implications for metabolic disease of fresh cows. Vet. Clin. North Am. Food Anim. Pract. 29:279-297.

Batistel, F., J. de Souza, and F. A. P. Santos. 2017. Corn grain processing method interacts with calcium salts of palm fatty acids supplementation on milk production and energy balance of early lactation cows grazing tropical pasture. J. Dairy Sci. 100:53435357.

Bauman, D. E., and W. B. Currie. 1980. Partitioning of nutrients during pregnancy and lactation: A review of mechanisms involving homeostasis and homeorhesis. J. Dairy Sci. 63:1514-1529.

Beam, S. W., and W. R. Butler. 1998. Energy balance, metabolic hormones, and early postpartum follicular development in dairy cows fed prilled lipid. J. Dairy Sci. 81:121-131.

Bell, A. W. 1995. Regulation of organic nutrient metabolism during transition from late pregnancy to early lactation. J. Anim. Sci. 73:2804-2819.

Bines, J. A., P. E. Brumby, J. E. Storry, R. J. Fulford, and G. D. Braithwaite. 1978. The effect of protected lipids on nutrient intakes, blood and rumen metabolites and milk secretion in dairy cows during early lactation. J. Agric. Sci. 91:135-150.

Boerman, J. P., J. de Souza, and A. L. Lock. 2017. Milk production and nutrient digestibility responses to increasing levels of stearic acid supplementation of dairy cows. J. Dairy Sci. 100:2729-2738.

Boerman, J. P., J. L. Firkins, N. R. St-Pierre, and A. L. Lock. 2015. Intestinal digestibility of long-chain fatty acids in lactating dairy cows: A meta-analysis and meta-regression. J. Dairy Sci. 98:88898903.

Bradford, B. J., K. Yuan, J. K. Farney, L. K. Mamedova, and A. J. Carpenter. 2015. Invited review: Inflammation during the transition to lactation: New adventures with an old flame. J. Dairy Sci. 98:6631-6650.

Cochran, R. C., D. C. Adams, J. D. Wallace, and M. L. Galyean. 1986. Predicting the digestibility of different diets with internal markers: Evaluation of four potential markers. J. Anim. Sci. 63:1476-1483.

Contreras, G. A., C. Strieder-Barboza, and W. Raphael. 2017. Adipose tissue lipolysis and remodeling during the transition period of dairy cows. J. Anim. Sci. Biotechnol. 8:41.

Davis, A. N., Z. C. Phipps, Q. Zeng, J. de Souza, J. E. Rico, A. L. Lock, and J. W. McFadden. 2017. Palmitic acid feeding increases plasma ceramide concentrations in Holstein dairy cows during early lactation. J. Dairy Sci. 100(E-suppl. 2):101. (Abstr.)

de Souza, J., and A. L. Lock. 2019. Effects of timing of palmitic acid supplementation on production responses of early-lactation dairy cows. J. Dairy Sci. 102:260-273. https://doi.org/10.3168/jds.2018 $-14976$.

de Souza, J., J. L. Garver, C. L. Preseault, and A. L. Lock. 2017. Effects of prill size of a palmitic acid-enriched fat supplement on yield of milk and milk components and nutrient digestibility of dairy cows. J. Dairy Sci. 100:379-384.

de Souza, J., C. L. Preseault, and A. L. Lock. 2018. Altering the ratio of dietary palmitic, stearic, and oleic acids in diets with or without whole cottonseed affects nutrient digestibility, energy partitioning, and production responses of dairy cows. J. Dairy Sci. 101:172-185.

Doreau, M., and Y. Chilliard. 1997. Digestion and metabolism of dietary fat in farm animals. Br. J. Nutr. 78(Suppl. 1):S15-S35.

Drackley, J. K. 2000. Lipid metabolism. Pages 97-119 in Farm Animal Metabolism and Nutrition. J. P. F. D’Mello, ed. CABI, New York, NY.

Freeman, C. P. 1969. Properties of fatty acids in dispersions of emulsified lipid and bile salt and the significance of these properties in fat absorption in the pig and the sheep. Br. J. Nutr. 23:249-263.

Goering, H. K., and P. J. Van Soest. 1970. Forage Fiber Analysis (Apparatus, Reagents, Procedures, and Some Applications). Agricultural Handbook no. 379. USDA Agricultural Research Service, Washington, DC.

González, F. D., R. Muiño, V. Pereira, R. Campos, and J. L. Benedito. 2011. Relationship among blood indicators of lipomobilization and hepatic function during early lactation in high-yielding dairy cows. J. Vet. Sci. 12:251-255.

Grummer, R. R. 1988. Influence of prilled fat and calcium salts of palm oil fatty acids on ruminant fermentation and nutrient digestibility. J. Dairy Sci. 71:117-123.

Grummer, R. R. 1993. Etiology of lipid-related metabolic disorders in periparturient dairy cows. J. Dairy Sci. 76:3882-3896.

Hackmann, T. J., and J. L. Firkins. 2015. Electron transport phosphorylation in rumen butyrivibrios: Unprecedented ATP yield for glucose fermentation to butyrate. Front. Microbiol. 6:622. https:// doi.org/10.3389/fmicb.2015.00622.

Harvatine, K. J., and M. Allen. 2006. Effects of fatty acid supplements on milk yield and energy balance of lactating dairy cows. J. Dairy Sci. 89:1081-1091.

Herdt, T. H. 2000. Ruminant adaptation to negative energy balance: Influences on the etiology of ketosis and fatty liver. Vet. Clin. North Am. Food Anim. Pract. 16:215-230.

Lock, A. L., C. L. Preseault, J. E. Rico, K. E. DeLand, and M. S. Allen. 2013. Feeding a C16:0-enriched fat supplement increased the yield of milk fat and improved feed efficiency. J. Dairy Sci. 96:6650-6659.

Mathews, A. T., J. E. Rico, N. T. Sprenkle, A. L. Lock, and J. W. McFadden. 2016. Increasing palmitic acid intake enhances milk production and prevents glucose-stimulated NEFA disappearance without modifying systemic glucose tolerance in mid-lactation dairy cows. J. Dairy Sci. 99:8802-8816.

McCarthy, M. M., T. Yasui, C. M. Ryan, S. H. Pelton, G. D. Mechor, and T. R. Overton. 2015. Metabolism of early-lactation dairy cows as affected by dietary starch and monensin supplementation. J. Dairy Sci. 98:3351-3365.

Moallem, U., M. Katz, A. Arieli, and H. Lehrer. 2007. Effects of peripartum propylene glycol or fats differing in fatty acid profiles on feed intake, production, and plasma metabolites in dairy cows. J. Dairy Sci. 90:3846-3856.

National Research Council. 2001. Nutrient Requirements of Dairy Cattle. 7th rev. ed. National Academy Press, Washington, DC.

Ockner, R. K., J. P. Pittman, and J. L. Yager. 1972. Differences in the intestinal absorption of saturated and unsaturated long chain fatty acids. Gastroenterology 62:981-992.

Ospina, P. A., J. A. McArt, T. R. Overton, T. Stokol, and D. V. Nydam. 2013. Using nonesterified fatty acids and $\beta$-hydroxybutyrate concentrations during the transition period for herd-level monitoring of increased risk of disease and decreased reproductive and milking performance. Vet. Clin. North Am. Food Anim. Pract. 29:387-412.

Ospina, P. A., D. V. Nydam, T. Stokol, and T. R. Overton. 2010. Associations of elevated nonesterified fatty acids and beta-hydroxybutyrate concentrations with early lactation reproductive performance and milk production in transition dairy cattle in the northeastern United States. J. Dairy Sci. 93:1596-1603. 
Overton, T. R., J. A. A. McArt, and D. V. Nydam. 2017. A 100year review: Metabolic health indicators and management of dairy cattle. J. Dairy Sci. 100:10398-10417.

Piantoni, P., A. L. Lock, and M. S. Allen. 2013. Palmitic acid increased yields of milk and milk fat and nutrient digestibility across production level of lactating cows. J. Dairy Sci. 96:7143-7154.

Piantoni, P., A. L. Lock, and M. S. Allen. 2015a. Saturated fat supplementation interacts with dietary forage neutral detergent fiber content during the immediate postpartum and carryover periods in Holstein cows: Production responses and digestibility of nutrients. J. Dairy Sci. 98:3309-3322.

Piantoni, P., A. L. Lock, and M. S. Allen. 2015b. Saturated fat supplementation interacts with dietary forage neutral detergent fiber content during the immediate postpartum period in Holstein cows: Energy balance and metabolism. J. Dairy Sci. 98:3323-3334.

Ribeiro, E. S., F. S. Lima, L. F. Greco, R. S. Bisinotto, A. P. A. Monteiro, M. Favoreto, H. Ayres, R. S. Marsola, N. Martinez, W. W. Thatcher, and J. E. P. Santos. 2013. Prevalence of periparturient diseases and effects on fertility of seasonally calving grazing dairy cows supplemented with concentrates. J. Dairy Sci. 96:5682-5697.

Rico, D. E., Y. Ying, and K. J. Harvatine. 2014. Effect of a highpalmitic acid fat supplement on milk production and apparent total-tract digestibility in high- and low-milk yield dairy cows. J. Dairy Sci. 97:3739-3751.

Rico, J. E., J. de Souza, M. S. Allen, and A. L. Lock. 2017a. Nutrient digestibility and milk production responses to increasing levels of palmitic acid supplementation vary in cows receiving diets with or without whole cottonseed. J. Anim. Sci. 95:436-446.

Rico, J. E., S. Saed Samii, A. T. Mathews, J. Lovett, N. J. Haughey, and J. W. McFadden. 2017b. Temporal changes in sphingolipids and systemic insulin sensitivity during the transition from gestation to lactation. PLoS One 12:e176787.
Simas, J. M., J. T. Huber, C. B. Theurer, K. H. Chen, F. A. P. Santos, and Z. Wu. 1998. Influence of sorghum grain processing on performance and nutrient digestibilities in dairy cows fed varying concentrations of fat. J. Dairy Sci. 81:1966-1971.

Sklan, D., M. Kaim, U. Moallem, and Y. Folman. 1994. Effect of dietary calcium soaps on milk yield, body weight, reproductive hormones, and fertility in first parity and older cows. J. Dairy Sci. $77: 1652-1660$.

Sordillo, L. M. 2016. Nutritional strategies to optimize dairy cattle immunity. J. Dairy Sci. 99:4967-4982.

Sordillo, L. M., G. A. Contreras, and S. L. Aitken. 2009. Metabolic factors affecting the inflammatory response of periparturient dairy cows. Anim. Health Res. Rev. 10:53-63.

Vlaeminck, B., V. Fievez, A. J. R. Cabrita, A. J. M. Fonseca, and R. J. Dewhurst. 2006. Factors affecting odd- and branched-chain fatty acids in milk: A review. Anim. Feed Sci. Technol. 131:389-417.

Weiss, W. P., and J. M. Pinos-Rodríguez. 2009. Production responses of dairy cows when fed supplemental fat in low- and high-forage diets. J. Dairy Sci. 92:6144-6155.

Weiss, W. P. and D. J. Wyatt. 2004. Digestible energy values of diets with different fat supplements when fed to lactating dairy cows. J. Dairy Sci. 87:1446-1454

Zachut, M., H. Honig, S. Striem, Y. Zick, S. Boura-Halfon, and U. Moallem. 2013. Periparturient dairy cows do not exhibit hepatic insulin resistance, yet adipose-specific insulin resistance occurs in cows prone to high weight loss. J. Dairy Sci. 96:5656-5669.

Zebeli, Q., K. Ghareeb, E. Humer, B. U. Metzler-Zebeli, and U. Besenfelder. 2015. Nutrition, rumen health and inflammation in the transition period and their role on overall health and fertility in dairy cows. Res. Vet. Sci. 103:126-136. 